\title{
Pola Manajemen Dakwah Mesjid Al Munawwaroh Sayati, Margahayu Kab. Bandung
}

\author{
Rima Mugia Restu Lestari*, Hendi Suhendi \\ Prodi Komunikasi Penyiaran Islam, Fakultas Dakwah, Universitas Islam \\ Bandung, Indonesia.
}

*xiiipd.rimamugia@gmail.com, Shendisf.unisba@gmail.com

\begin{abstract}
Management patterns in an organization are very important in carrying out a plan. The mosque management pattern is very important as an effort to improve the mosque from within the form of strengthening the existence of the mosque as a place of worship for Muslims. AL Munawwaroh Mosque is one of the mosques built in Sayati village, Bandung district. The existence of this mosque has been known by several outside congregations and in the implementation of its management there have been many developments from time to time, especially in the aspect of Islamic da'wah activities. The author examines how the Management Pattern of the AL Munawwaroh Mosque in increasing Islamic da'wah activities. The purpose of this study was to determine the management pattern of the al Munawwaroh mosque in increasing its preaching activities. The benefit of this research is to enrich the scientific treasures of management and sran for the improvement of other mosques. Research conducted by the author is a case study researcher with a qualitative approach, in order to provide clarity on the problem or event under study. Thus the population of this research is the management of the Al Munawwaroh Mosque, the congregation, and community leaders. This study uses interview data collection techniques, observation, and documentation. Interviews were conducted with mosque administrators who were directly involved with the applied management of the mosque. The results of the study found that first, the management pattern carried out by the management of the AL Munawwaroh Mosque was the planning, organizing, implementing, and monitoring patterns. Where all the patterns above are carried out together by the board, the congregation. Second, Islamic da'wah activities carried out by the Al Munawwaroh mosque are in accordance with what has been planned in the management pattern. Third, the management of the Al Munawwaroh mosque from the start of construction, finance, and daily worship services is quite good.
\end{abstract}

Keywords: Mosque Management, Da'wah Activities

Abstrak. Pola manajemen dalam sebuah organisasi sangatlah penting dalam menjalankan sebuah perencanaan. Adapun pola manajemen masjid sangat penting sebagai suatu upaya perbaikan masjid dari dalam berupa penguatan eksistensi masjid sebagai tempat peribadahan umat islam. Masjid AL Munawwaroh merupakan salah satu masjid yang dibangun di desa sayati kab bandung. Keberadaan masjid ini sudah dikenal oleh beberapa Jemaah luar dan dalam pelaksanaan manajemennya sudah banyak perkembangan dari masa ke masa, khusunya pada aspek aktivitas dakwah islam. Penulis meneliti bagaimana Pola Manajemen Masjid AL Munawwaroh dalam meningkatkan aktivitas dakwah islam. Tujuan penelitian ini adalah untuk mengetahui pola manajemen yang dilakukan masjid al Munawwaroh dalam meningkatkan aktivitas dakwahnya. Manfaat penelitian ini untuk memperkaya khazanah keilmuan manajemen dan sran bagi perbaikan masjid lainnya. Penelitian yang dilakukan oleh penulis merupakan penelitia studi kasus dengan pendekatan kualitatif, guna memberikan kejelasan terhadap masalah atau peristiwa yang diteliti. Demikian yang menjadi populasi peneliti ini adalah pengurus Mesjid Al Munawwaroh, Jemaah, dan tokoh masyarakat. Penelitian ini menggunakan teknik pengumpulan data wawancara, observasi, dan dokumentasi. Wawancara yang dilakukan kepada pengurus masjid yang terlibat langsung dengan manajemen masjid yang diterapkan. Hasil penelitian menemukan, bahwa yang pertama, pola manajemen yang dilakukan oleh pengurus Mesjid AL Munawwaroh ialah dengan Pola Perencanaan, pengorganisasian, Pelaksanaan, dan pengawasan. Dimana semua pola diatas dilakukan bersama oleh pengurus, Jemaah. Kedua, aktivitas dakwah islam yang dijalankan oleh masjid Al Munawwaroh sesuai dengan apa yang telah direncanakan pada pola manajemen. Ketiga, pengelollan masjid Al Munawwaroh dari mulai pembangunan, keuangan, sera ibadah harian sudah cukup baik dilaksanakan.

Kata Kunci: Manajemen Masjid, Aktivitas Dakwah 


\section{A. Pendahuluan}

Masjid merupakan tempat beribadah umat islam. Dapat diartikan pula sebagai tempat sujud, yaitu sebagai tempat untuk umat islam melaksanakan kewajibannya. Sering sekali banyak orang mukmin yang berlomba-lomba dalam membangun atau mewakafkan hartanya untuk masjid, karena pahalanya pun besar dan menjadi bekal untuk nanti di akhirat. salah satu pahala membangun masjid yaitu seperti membangun rumah di surga dan menjadi amal jariyyah yang tidak akan pernah putus. seperti dijelaskan dalam hadits "musnad Ahmad bin Hanbal, 1;84, no. 506, shohih Muslim IX: 222, no. 7662, sunan Ad-darimi, 1: 376, no. 1392

$$
\text { وَمَنْ بَنَى لِلهِ مَسْجِدًا بَنَى اللَهُ لَهُ بَيْتَا فِي الْجَنَّة }
$$

Artinya : " barang siapa yang mendirikan masjid karena Allah, Allah akan mendirikan gedung seperti itu di surga" musnad Ahmad bin Hanbal, 1;84, no. 506, shohih Muslim IX: 222, no. 7662, sunan Ad-darimi, 1: 376, no. 1392"

Fungsi masjid bagi umat Islam yang paling utama sebagai tempat beribadah kepada allah, dzikrullah, dan membaca Al qur'an. Hal ini sebagaimana dalam salahsatu surat Al-Qur'an, Allah SWT berfirman :

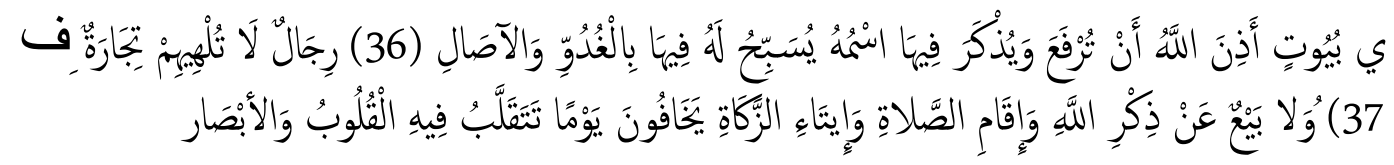

Artinya : (36) "Bertasbih kepada Allah di masjid-masjid yang telah diperintahkan untuk dimuliakan dan disebut nama-Nya di dalamnya, pada waktu pagi dan waktu petang. (37) Lakilaki yang tidak dilalaikan oleh perniagaan dan tidak (pula) oleh jual beli dari mengingati Allah, dan (dari) mendirikan sembahyang, dan (dari) membayarkan zakat. Mereka takut kepada suatu hari yang (dihari itu) hati dan penglihatan menjadi goncang. (QS An-Nur 36-37)

Selain itu, masjid memiliki fungsi lain yang berperan dalam perkembangan dakwah umat islam. Yaitu: sebagai pusat pendidikan, tempat musyawarah, dan tempat sosial lainnya yang berkaitan dengan dakwah.

Aktivitas dakwah pada awalnya hanyalah merupakan tugas sederhana yakni kewajiban untuk menyampaikan apa yang diterima dari Rasulullah, walaupun satu ayat. Inilah yang membuat kegiatan atau aktivitas dakwah boleh dan harus dilakukan oleh siapa saja yang mempunyai rasa keterpanggilan untuk menyebarkan nilai-nilai Islam. itulah sebabnya aktivitas dakwah memang harus berangkat dari kesadaran pribadi yang dilakukan oleh per orang dengan kemampuan minimal dari siapa saja yang melakukan dakwah tersebut.

Aktivitas Dakwah. Ialah aktivitas yang dilakukan dengan mengajak, mendorong, menyeru tanpa tekanan dan atau provokasi. Seperti Q.S An-Nahl ayat 6:125 Firman Allah SWT:

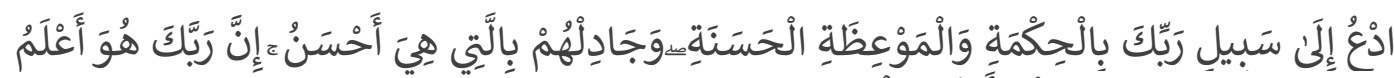

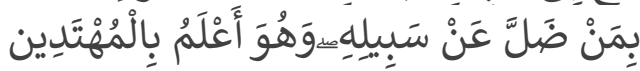

"Serulah manusia kepada jalan Tuhanmu dengan hikmah dan pelajaran yang baik dan bantahlah mereka dengan cara yang baik. Sesungguhnya Tuhanmu Dialah yang lebih mengetahui orang-orang yang mendapat petunjuk".

Sebagai contoh, masjid Al Munawwaroh sebagai objek peneliti penulis merupakan masjid yang berada di tengah padat penduduk, semua kalangan masyarakat dari berbagai macam pekerjaannya, usianya, serta pendidikannya yang berbeda jenjang menghasilkan masyarakat yang sangat heterogen. Kegiatan aktivitas dakwahpun sering dilakukan karena menyesuaikan dan membagi kajian umum, pengajian ibu-ibu, serta kajian remaja. Hingga dalam seminggu ada hampir 4x aktivitas dakwah yang dilakukan.

Kegiatan dakwah di masjid Al Munawwaroh terbilang sangat rutin, konsistnsi para jamaah pun tidak berkurang. Semua pemateri yang diundang selalu merujuk kepada tema yang dibutuhkan oleh jamaah dan masyarakat setempat. Tujuan dakwah yang di tekankan oleh masjid 
Al Munawwaroh dari segi da'I yang berkualitas yang mampu dan paham akan keadaan jamaah di masjid Al munawwaroh, dari segi Materi yang disampaikan, suatu bekal untuk para Jemaah dalam menimba ilmu dan menambah pengetahuan dibidang agama dan umum, dan Metode yang disampaikan oleh para da'i harus sesuai dengan masyarakat setempat.

Dari pemaparan diatas maka penulis mengambil Gambaran umum tentang permasalahan yang terjadi di masjid Almunawwaroh. Berdasarkan observasi singkat dilakukan penulis kepada perwakilan Jemaah tentang aktivitas dakwah yang terjadi di masjid Almunawwaroh ditemukan beberapa permasalahan diantaranya: 1) Dari segi da'i, penyampaian yang kurang jelas, bahasa yang digunakan terkadang terlalu ilmiah. 2) dari segi materi, penyampaian materi yang terkadang bahasa yang diucapkan terlalu frontal atau bahasa yang tidak seharusnya diucapkan. 3) Dari segi Metode, penyampaian yang dirasa kurang dalam memberikan pemahaman kepada jemaah.

Adapun tujuan penelitian ini adalah:

1. untuk mengetahui apa tujuan pengelolaan masjid Al Munawwaroh desa sayati kec margahayu kab bandung.

2. Untuk mengetahui aktivitas dakwah Islam di masjid Al- Munawarah desa sayati kec margahayu kab bandung.

3. Untuk mengetahui pola manajemen masjid Al- Munawarah desa sayati kec margahayu kab bandung dalam peningkatan aktivitas dakwah.

\section{B. Landasan Teori}

\section{Manajemen Masjid}

\section{Pengertian Manajemen Masjid}

Manajemen masjid berasal dari dua kata, yaitu manajemen dan masjid. Masjid berasal dari kata sajada bermakna tempat sujud/sholat. Masjid bukan milik pribadi, tapi milik bersama yang harus diurus secara bersama-sama dengan kerjasama yang baik. Sedangkan manajemen, berasal dari kata manage yang berarti mengurus, membimbing, mengawasi, mengelola atau mengatur. Atau manajemen adalah proses perencanaan, pengorganisasian, pengarahan, dan pengawasan usaha-usaha para anggota organisasi dan penggunaan sumber daya, sumber daya organisasi lainnya agar mencapai tujuan organisasi yang telah ditetapkan.

Manajemen masjid atau Idarah masjid ialah ilmu dan usaha yang meliputi segala tindakan dan kegiatan muslim dalam menempatkan masjid tsebagai tempat ibadah dan pusat kebudayaan Islam. Moh,E,.Ayub mendefinisikan Idarah masjid adalah usaha-usaha untuk merealisasikan fungsi-fungsi masjid sebagaimana fungsinya. Idarah masjid ialah suatu proses atau usaha mencapai kemakmuran masjid yang ideal, dilakukan oleh seorang pemimpin pengurus masjid bersama staf dan jamaanya melaluiberbagai aktifitas yang positif. Kepengurusan masjid menggunakan manajemen yang baik, akan ada banyak manfaat yang diperoleh yaitu:

1. Tujuan atau target yang hendak dicapai akan diterumuskan dengan jelas dan matang.

2. Usaha mencapai tujuan pemakmuran masjid bisa dilaksanakan secara bersama-sama dengan kerja sama yang baik melalui koordinasi yang rapi, sehingga meskipun tugas atau perkerjaan sebagai pengurus masjid berat, dapat dilaksanakan dengan ringan.

3. Dapat dihindari terjadinya tumpang tindih antara pengurus yang satu dengan yang lainnya.

4. Pelaksanaan tugas-tugas memakmurkan masjid dapat dilaksanakan secara efektif dan efesien

5. Pengontrolan dan evaluasi bisa dilaksanakan dengan menggunakan standar atau tolak ukur yang jelas.

6. Gejala penimpanan kerja dapat dicegah, karena mudah mendeteksinya, dan bila penyimpanan betul-betul bisa dihentikan.

Jika dua kata tersebut dipadukan, maka dapat disimpulkan bahwa Manajemen Masjid adalah proses/usaha mencapai kemakmuran masjid yang ideal yang dilakukan oleh pemimpin pengurus masjid bersama staf dan jama'ahnya melalui berbagai aktivitas yang positif. Secara 
umum manajemen mencakup kegiatan untuk mencapai tujuan. Dilakukan oleh individu-individu yang menyumbankan upaya terbaik melalui tindakan-tindakan yang lebih ditetapkan sebelumnya.

\section{Teori Aktivitas Dakwah Islam}

\section{Pengertian Dakwah}

Secara semantik, dakwah berarti memanggil, mempersilakan, memohon, propaganda dan menyebarkan, baik ke arah yang baik maupun ke arah yang buruk. Dalam ilmu tata Bahasa Arab, kata dakwah merupakan bentuk mashdar dari kata kerja $d a$ 'a, yad'u, da'watan, yang berarti memanggil, menyeru, atau mengajak.

Maka secara definisi bahasa dakwah intinya adalah menyeru atau mengajak, adapun definisi menurut para ahli adalah sebagai berikut:

1. Musyawarah kerja Nasional-IPTDI di Jakarta (1968) merumuskan dakwah adalah "Menggajak atau menyeyru untuk melakukan kebajikan dan mencegah kemungkaran, mengubah umat dari satu situasi kepada situasi lain yang lebih baik dalam segala bidang, merealisasi ajaran Islam dalam kehidupan sehari-hari bagi seorang pribadi, keluarga, kelompok atau massa, serta bagi kehidupan masyarakat sebagai keseluruhan tata hidup bersama dalam rangka pembangunan bangsa dan umat manusia"

2. Syekh Muhammad al-Ghazali (dalam al-Bayanuni, 1993: 15), dakwah adalah:

"Program sempurna yang menghimpun semua pengetahuan yang dibutuhkan oleh manusia di semua bidang, agar ia dapat memahami tujuan hidupnya serta menyelidiki petunjuk jalan yang mengarahkannya menjadi orang-orang yang mendapat petunjuk".

3. Sedangkan jika definisi dakwah menekankan pada asfek motivasi menurut penggagasnya yaitu Syekh Ali Mahfudz dakwah adalah "upaya membangkitkan kesadaran manusia di atas kebaikan dan bimbingan, menyuruh berbuat ma'ruf fan mencegah terhadap yang munkar supaya mereka mendapat kebahagiaan di dunia dan di akhirat"

Pemaparan banyak definisi dakwah diatas dimaksudkan untuk membandingkan, memetakan, dan menelusuri perkembangan definisi dakwah. Umumnya para ahli membuat definisi dakwah berangkat dari pengertian dakwah menurut bahasa. Kata-kata seruan, anjuran, ajakan, dan panggilan selalu ada dalam definisi dakwah ini menunjukan mereka sepakat bahwa dakwah bersifat persuasif bukan represif. Mereka setuju dengan dakwah informatif, bukan manipulatif. Bukanlah termasuk dakwah, jika ada tindakan yang memaksa orang lian untuk memilih antara hidup sebagai muslim ataukah mati terbunuh. Tidaklah disebut dakwah, bila ajakan kepada Islam dilakukan dengan memutarbalikan pesan Islam untuk kepentingan duniawi seseorang atau kelompok.

\section{Pengertian Aktivitas}

Dalam kamus besar bahasa Indonesia, aktivitas diartikan sebagai segala bentuk keaktifan dan kegiatan. Aktivitas adalah keaktifan, kegiatan-kegiatan, kesibukan atau bisa juga berarti kerja atau salah satu kegiatan kerja yang dilaksanakan tiap bagian dalam tiap suatu organisasi atau lembaga.

Menurut ilmu sosiologi aktivitas diartikan sebagai segala bentuk kegiatan yang ada di masyarakat seperti gotong royong dan kerja sama disebut sebagai aktivitas sosial baik yang berdasarkan hubungan tetangga atau kekerabatan.

Dalam kehidupan sehari-hari banyak sekali aktivitas, kegiatan, atau kesibukan yang dilakukan manusia. Namun, berarti atau tidaknya kegiatan tersebut bergantung pada individu tersebut.Karena, menurut Samuel soeitoe sebenarnya, aktivitas bukan hanya sekedar kegiatan, beliau mengatakan bahwa aktivitas, dipandang sebagai usaha mencapai atau memenuhi kebutuhan.

\section{Aktivitas Dakwah}

Adapun bentuk Aktivitas yang dilakukan Nabi Muhammad SAW sebagaimana berikut :

1. Dakwah Fardhiyah

Dakwah dengan pendekatan pribadi ini dimulai dengan mengajak para anggota keluarga dan 
para sahabatnya yang terdekat.Beliau menyeru mereka kepada Islam, juga menyeru siapa pun yang dirasa memiliki kebaikan, yang sudah beliau kenal secara baik dan mereka pun mengenal beliau secara baik, yaitu mereka yang memang diketahui mencintai kebaikan dan kebenaran, dan mereka mengenal kejujuran dan kelurusan beliau.

2. Tabligh

Artinya: "Dan berilah peringatan kepada kerabat-kerabatmu yang terdekat", (QS. AsySyu"ara": 214) Setelah turun ayat di atas, Rasulullah SAW segera mengundang Bani Hasyim. Mereka memenuhi undangan ini, yaitu beberapa orang dari Bani Al-Muthalib bin Abdi Manaf, yang jumlahnya 45 orang. Tabligh pertama Nabi ini tidak berjalan sesuai harapan, karena Abu Lahab segera angkat bicara merusak suasana dan tidak memberikan kesempatan kepada Nabi untuk berbicara. Meskipun begitu, tabligh ini membuahkan hasil yang patut disyukuri, yakni adanya deklarasi penjagaan dan perlindungan dari Abu Thalib.

3. Dialog

Hal lain yang dilakukan Nabi SAW dalam perjuangan dakwahnya adalah kegiatan dialog. Dalam sejarah dicatat bahwa beliau pernah berdialog dengan para tokoh Quraisy dan juga dengan kalangan Ahli Kitab (Yahudi dan Nasrani). Salah satu contoh adalah dialog Nabi SAW dengan Utbah bin Rabiah yang diutus kaum Quraisy untuk membujuk Nabi. Dialog tersebut berakhir dengan kemenangan telak di pihak Nabi, karena Utbah takluk dan terpengaruh oleh Al-Qur"an surah Fushilat ayat 1 sampai 13 yang dibacakan kepadanya. Ia mendengar ultimatum yang menggoncangkan segenap perasaannya, yaitu: Jika mereka berpaling Maka Katakanlah: "Aku Telh memperingatkan kamu dengan petir, seperti petir yang menimpa kaum ,Aad dan Tsamud”. (QS. Fushilat: 13)

4. Mengirim Mubaligh

Salah satu bentuk dakwah Nabi saw adalah bietsatudu"eat (pengiriman daeii). Beliau mengutus Mush"eab bin Umair dan Abdullah bin Ummimaktum ke Madinah untuk mengajarkan Islam. Maka, penyiaran agama Islam di Madinah makin hari makin bertambah pesat kemajuannya.

\section{Unsur-Unsur Dakwah}

\section{Tujuan Dakwah}

Dakwah bertujuan menciptakan suatu tatanan kehidupan individu dan masyarakat yang aman, damai, dan sejahtera yang dinaungi oleh kebahagiaan, baik jasmani maupun rohani, dalam pancaran sinar agama Allah dengan mengharap ridha-Nya. Suatu tujuan dakwah seyogianya dicermati dengan baik agar dapat membuahkan keluaran yang terukur.

Spirit Amar Ma'ruf dan Nahyi Munkar merasuk kedalam elemen-elemen kehidupan menjadi barometer aktivitas kehidupan kaum muslim yang dilaksanakan secara terencana, berkesinambungan, fleksibel, dan dinamis. Dakwah berdinamika sepanjang zaman dan tetap mencari keseimbangan dalam interaksi sosial. Meskipun demikian, nilai-nilai Islam tetap berlangsung dalam berbagai kondisi yang baik. Perkembangan yang ada diantisipasi oleh Islam. artinya, kaum muslim harus maju karena kemajuan merupakan kodrat manusia (Al-insan madaniy bi I-thabi'ie). Oleh karena itu, ia tidak boleh meninggalkan kebajikan substansial yang telah diajarkan oleh Islam. teknologi harus mampu menyejahterakan kaum muslim, dan menjadi sesuatu yang positif bagi perkembangan manusia secara keseluruhan. Teknologi yang berujung pada pendegradasian martabat manusia harus ditinggalkan dan direstrukturisasi.

Senada dengan pernyataan di atas Amrullah Ahmad membagi tujuan dakwah pada dua garis besar, yaitu tujuan jangka pendek (mikro) dan tujuan jangka panjang (makro). Tujuan jangka pendek (mikro) lebih menajam kepada upaya peningkatan insan-insan berkualitas, membangun manusia-manusia shaleh, merubah stratifikasi yang rendah kepada yang lebih baik dan terhormat. Sedangkan tujuan jangka panjang (makro) adalah membangun kehidupan masyarkat yang berkualitas dengan perkataan lain "baldatun thoyyibatun warobbun ghofur" yaitu negeri yang baik dn Tuhan memberi ampunan, atau istilah lain disebut masyarakat madani, yaitu tatanan masyarakat yang diliputi kehidupannya oleh iman dan taqwa 
Da'i

Da'i (subjek dakwah), kata da'i berasal dari bahasa arab yang berarti orang yang mengajak. Dalam kamus bahasa Indonesia da'i diartikan sebagai orang yang pekerjaannya berdakwah, pendakwah. Melalui kegiatan dakwah da'i menyebar luaskan ajaran Islam. Dengan kata lain da'i adalah orang yang mengajak kepada orang lain baik secara langsung atau secara tidak langsung, melalui lisan, tulisan, atau perbuatan untuk mengamalkan ajaran Islam atau menyebar luaskan ajaran Islam, melakukan upaya perubahan kearah kondisi yang lebih baik menurut ajaran Islam. Da'i dalam posisi ini disebut subjek dakwah yaitu pelaku dakwah yang senantiasa aktif menyebarluaskan ajaran islam.

Adapun karakteristik yang harus dimiliki oleh seorang da'I yaitu : ilmu yang bermanfaat, beriman kepada Allah, sabar, berakhlaq dengan akhlaq yang mulia, ikhlas dalam melakukan ibadah, dan mempunyai sifat shidiq.

\section{Mad'u}

Mad'u (objek dakwah), adalah seluruh manusia sebagai makhluk Allah yang dibebani menjalankan agama Islam dan diberi kebebasan untuk berikhtiar, kehendak dan bertanggungjawab atas perbuatan sesuai dengan pilihannya, mulai dari individu, keluarga, kelompok, golongan, kaum, massa, dan umat seluruhnya.

\section{Materi}

Pada umumnya, materi yang disampaikan dalam dakwah, adalah ajaran-ajaran yang disyariatkan dalam Islam. Ajaran-ajaran Islam yang menitikberatkan pada bangunan Akhlaqul Karimah inilah, yang wajib untuk disampaikan kepada manusia, yang nantinya diharapkan supaya ajaran-ajaran tersebut dapat diketahu, dipahami, dihayati, serta diamalkan dalam bingkai kehidupan mereka sehari-hari, sehingga hidup mereka senantiasa dalam suasana religi, yang tentunya sesuai dengan tuntunan agama Islam.

Ajaran-ajaran yang dibawa dan diajarkan Rasulullah kepada umatnya ini meliputi aspek duniawi dan ukhrawi, yang tentunya materi yang harus diserukan dalam dakwah pun menjadi luas sekali. Adapun di antara materi-materi tersebut, kiranya dapat kita ringkas menjadi beberapa pokok pembahasan diantaranya:

1. Akidah Islam, yang meliputi tauhid dan keimanan.

2. Pembentukan pribadi yang sempurna, dengan berpondasikan pada nilai-nilai Akhlaqul Karimah.

3. Pembangunan masyarakat yang adil dan makmur.

4. Kemakmuran dan kesejahteraan di dunia dan akhirat.

5. Dan pembahasan yang lainnya.

Adapun menurut Endang Saepudin Anshari materi dakwah adalah al-Islam (Al-Quran dan Al-Sunah) tentang berbagai soal perikehidupan dan penghidupan manusia. Selanjutnya Muhaemin menjelaskan secara umum pokok isi Al-Quran meliputi hal sebagai brerikut:

1. Akidah, yaitu aspek ajaran Islam yang berhubungan dengan keyakinan, meliputi rukun iman, atau segala sesuatu yanh harus diimani dan diyakini menurut A-Quran dan AlSunah.

2. Ibadah, aspek ajaran Islam yang berhubungan dengan kegiatan ritual dalam rangka pengabdian kepada Allah SWT.

3. Muamalah, aspek ajaran Islam yang megajarkan berbagai aturan dalam tata hehidupan bersosial (bermasyarakat) dalam berbagai aspeknya.

4. Akhlak, aspek ajaran Islam yang berhubungan dengan tata prilaku manusia sebagai hamba Allah, anggota masyarakat, dan bagian dari alam sekitarnya.

5. Sejarah, peritiwa-peristiwa perjalanan hidup yang sudah dialami umat manusia yang diterangkan Al-Quran untuk senantiasa diambil hikmahnya dan pelajarannya.

6. Prinsip-prinsip pengetahuan dan teknologi, yaitu aspek petunjuk-petunjuk singkat yang memberikan dorongan kepada manusia untuk mengadakan analisa dan mempelajari isi alam dan perubahan-perubahannya.

7. 
Metode

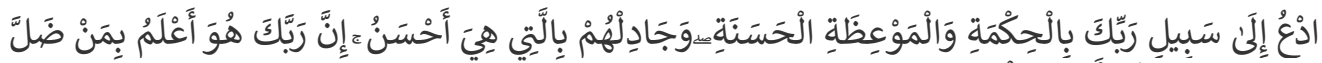

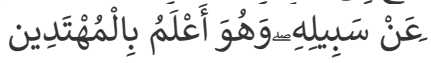

"Serulah manusia kepada jalan Tuhanmu dengan hikmah dan pelajaran yang baik dan bantahlah mereka dengan cara yang baik. Sesungguhnya Tuhanmu Dialah yang lebih mengetahui orangorang yang mendapat petunjuk." (An-Nahl [16]: 125).

Dalam ayat ini Allah SWT memberikan pedoman-pedoman kepada Rasul-Nya tentang cara mengajak manusia (dakwah) ke jalan Allah. Yang dimaksud jalan Allah disini ialah agama Allah yakni syari'at Islam yang diturunkan Nabi Muhammad saw. Allah SWT dalam ayat ini meletakan dasar-dasar dakwah untuk pegangan bagi umatnya dikemudian hari dalam mengemban tugas dakwah

Pertama yaitu dengan Al-Hikmah. Kata "Hikmah" dalam Al-Qur'an disebutkan sebanyak 20 kali baik dalam bentuk nakiroh maupun ma'rifat. Bentuk masdarnya adalah "hukman" yang diartikan secara makna aslinya adalah mencegah. Jika dikaitkan dengan hukum berarti mencegah dari kedzaliman, dan jika dikaitkan dengan dakwah maka berarti menghindari hal-hal yang kurang relevan dalam melaksanakan tugas dakwah.

\section{Media Dakwah}

Dalam perkembangannya media dianggap menjadi salah saturi hal yang sangat penting dalam dakwah sehingga pesan yang ingin disampaikan bisa diterima dengan baik oleh mad'u. Menurut bahasa media sendiri di dalam bahasa arab disebut wasilah (wasilah, wasail) atau biasa disebut al-wuslah atau al-ittasal yang artinya segala hal yang dapat mengantarkan tercapainya kepada sesuatu yang dimaksud. Sedangkan media dakwah menurut Muhammad Munir dam Wahyu Ilahi yaitu alat yang digunakan sebagai perantara untuk melaksanakan kegiatan dakwah diantaranya antara lain.

1. Lisan: Da'wah bil lisan yaitu penyampaian informasi atas pesan dakwah melalui lisan.

2. Tulisan: Da'wah bil qalam yaitu penyampaian materi dakwah dengan menggunakan media tulisan.

3. Audio Visual: Dakwah dengan media audio visual merupakan suatu cara penyampaian yang merangsang penglihatan serta pendengaran audience.

4. Keteladanan: Suatu cara penyampaian dakwah yang dilakukan dalam bentuk perbuatan nyata. Ia tidak banyak berbicara, namun langsung mempraktikkannya. Ia tidak menganjurkan, tetapi langsung memberi contoh kepada mad'u-nya.

5. Sedangkan menurut Said Mubarak media dakwah atau wasilah dakwah yaitu alat yang menjadi perantara untuk menyampaikan sesuatu kepada yang dituju. Selanjutnya, menurut beliau terdapat dua bentuk media dakwah, yakin:

6. Maknawiyah, yaitu suatu perantara atau media yang mesti dilakukan oleh seorang da'i dalam berdakwah, berusaha keras mencari materi yang baik, serta waktu dan tempat yang tepat guna kegiatan dakwah.

7. Madiyah, yaitu media berupa: (1). Tatbiqiyah, seperti masjid, aula dan pusat dakwah islam lainnya. (2). Taqniyah, seperti pengeras suara dan berbagai peralatan modern lainnya. (3). Asasiyah, berupa ucapan seperti nasehat dan wejangan serta gerakan menempuh perjalanan.

\section{Hasil Penelitian dan Pembahasan}

Dari hasil penelitian diatas bahwa:

Setiap masjid mempunyai tujuan yang sama, yaitu untuk memakmurkan tempat yang dibangun untuk beribadah kepada Allah SWT. sama seperti tujuan masjid Al Munawwaroh. Dimana adanya masjid ini berdampak besar kepada jemaahnya. Pengamalan yang tidak bersifat individu melainkan komunal dan kolektif.

Aktivitas dakwah Masjid Al-Munawwaroh dibagi menjadi empat. Pertama untuk pengelolaan dakwah secara umum seperti pengajian rutin umum, tabligh akbar, jum'atan, 
kegiatan dakwah bulan Ramadhan ini secara langsung dipegang oleh bidang dakwah. Bagian kedua adalah Majelis Ta'lim ibu-ibu yang memiliki otonomi tersendiri. Dipegang dan dikelola oleh majlis ta'lim, baik penjadwalan maupun adminitrasi. ketiga adalah kegiatan remaja atau pemuda/i. Bidang dakwah ini pun memiliki bagian tersendiri yang dikelola oleh Remaja Masjid Al-Munawwaroh. Terakhir, adalah kegiatan dakwah bagi anak-anak seperti madrasah diniyyah awwaliyah dan pengajian maghrib yang dipegang langsung oleh lembaga DTA Al-Munawwaroh.

Pola manajemen yang dilakukan oleh masjid Al- Munawwaroh pada 4 unsur yang terdiri dari : perencanaan, pengorganisasian, pelaksaaan, dan pengawasan.

1. Pola perencanaan masjid $\mathrm{Al}$ Munawwaroh memulai dengan musyawarah sebagaimana untuk menentukan ide, gagasan, baik dari jamaah, masyarakat, maupun pengurus masjid. Selanjutnya dimasukan ke dalam forum pengurus DLM untuk ditindk lanjuti apakah baik untuk dijalankan, atau hanya sekedar ditampung terlebih dahulu.

2. Pola pengorganisasian masjid Al Munawwaroh yang sudah beberapa kali ganti kepengurusan menjadi evaluasi ketika menenukan orang-orang yang akan menjadi pengurus. Karena, tidak sembarang orang mampu menjadi pengurs. Dilihat dari kesungguhannya, rajin dalam beribadah ke masjid, dan tidak lain mempunyai semangat besar untuk selalu memakmurkan masjid.

3. Dari pola inipun bisa dilihat seberapa besar kekompakan setiap pengurus dalam mensukseskan semua yang telah direncanakan. Semua yang terlibat didalamnya mampu berkolaborasi, terjun langsung dalam beberapa kegiatan dakwah masjid. Ini yang menjadi catatan penting dari ketua $\mathrm{dkm}$ masjid Al Munawwaroh, beliau mengatakan :

4. "Kami disini semua saudara. Maka, dalam pembentuka kepengurusan kami secara garis besar sudah bisa menilai orang ini cocoknya di bagian apa, dan kelebihan orang itu mampu memberikan energy positif untuk keberlangsungannya kepengurusan kami. Meskipun tidak ada manusia yang sempurna, in syaa Allah kami disini saling melengkapi"

5. Pola pelaksanaan yang dilakukan oleh masjid Al Munawwaroh tentu akan menjadi tugas seluruh pengurus, bahkan seluruh jamaah dan masyarakat disekitar masjid. Karena yang berusaha dibentuk dan dibangun oelh pengurus DKM adalah keshalehan dan ketaqwaan komunal bukan personal. Walaupun untuk tanggung jawab pelaksanaan ini diserahkan kepada pengurus terkait. Misalkan dalam ranah pengajian dan pendidikan diserahkan kepada bidangn dakwah dan pendidikan, urusan renovasi diserahkan kepada bidang pengawasan dan pengurus bangunan.

6. pola pengawasan itu tetap menjadi tugas bersama pula, tidak hanya jamaah dan pengurus masjid. Namun aparat setempat seperti RT/RW menjadi pengasan dalam berlangsungnya kegiatan dakwah disini. Hal ini pula menjadi kekuatan dakwah di masjid Al Munawwaroh. Adanya legitimasi dan dukungan penuh dari para pejabat setempat yang memang hanya masjid satu-satunya yang berbeda di masjid-mesjid sekitarnya. Dilingkungan masjid AL Munawwaroh rata-rata memiliki banyak masjid dalam satu lingkungan, sehingga unsur-unsur pendukung yang ada menjadi terpecah dan terpisah.

\section{Kesimpulan}

Berdasarkan hasil penelitian dan pembahasan peneliti terkait pola manajemen masjid $\mathrm{Al}$ Munawwaroh dalam peningkatan aktivitas dakwah islam di desa sayati kec margahayu yang telah dilakukan pada bab sebelumnya, maka peneliti megambil kesimpulan sebagai berikut :

1. Tujuan pengelolaan masjid Al Munawwaroh untuk kemakmuran masjid dan kampung. Yang kehadiran masjid ini dalam pengelolaannya berdampak kepada masyarakat, yakni peningkatan kesholehannya tidak hanya individual tapi komunal, kolektif, atau bersamaan. Serta kenyaman Jemaah dalam beribadah menjadi point penting bagi pengurus dalam meningkatkan pengelolaan masjid Al Munawwaroh. 
2. Aktivitas dakwah Masjid Al-Munawwaroh dibagi menjadi empat. Pertama untuk pengelolaan dakwah secara umum seperti pengajian rutin umum, tabligh akbar, jum'atan, kegiatan dakwah bulan Ramadhan ini secara langsung dipegang oleh bidang dakwah. Bagian kedua adalah Majelis Ta'lim ibu-ibu yang memiliki otonomi tersendiri. Dipegang dan dikelola oleh majlis ta'lim, baik penjadwalan maupun adminitrasi. ketiga adalah kegiatan remaja atau pemuda/i, kegiatan dakwah ini pun memiliki bagian tersendiri yang dikelola oleh Remaja Masjid Al-Munawwaroh. Terakhir, adalah kegiatan dakwah bagi anak-anak seperti madrasah diniyyah awwaliyah dan pengajian maghrib yang dipegang langsung oleh lembaga DTA Al-Munawwaroh.

3. Pola manajemen masjid yang dilakukan oleh masjid $\mathrm{Al}$ munawwaroh sebagai berikut:

Pertama Dalam pola perencanaan masjid Al Munawwaroh memulai dengan musyawarah sebagaimana untuk menentukan ide, gagasan, baik dari jamaah, masyarakat, maupun pengurus masjid. Selanjutnya dimasukan ke dalam forum pengurus DLM untuk ditindk lanjuti apakah baik untuk dijalankan, atau hanya sekedar ditampung terlebih dahulu.

Kedua pola pengorganisasian masjid Al Munawwaroh yang sudah beberapa kali ganti kepengurusan menjadi evaluasi ketika menenukan orang-orang yang akan menjadi pengurus. Karena, tidak sembarang orang mampu menjadi pengurs. Dilihat dari kesungguhannya, rajin dalam beribadah ke masjid, dan tidak lain mempunyai semangat besar untuk selalu memakmurkan masjid.

Ketiga Pola pelaksanaan yang dilakukan oleh masjid Al Munawwaroh tentu akan menjadi tugas seluruh pengurus, bahkan seluruh jamaah dan masyarakat disekitar masjid. Karena yang berusaha dibentuk dan dibangun oleh pengurus DKM adalah keshalehan dan ketaqwaan komunal bukan personal. Walaupun untuk tanggung jawab pelaksanaan ini diserahkan kepada pengurus terkait. Misalkan dalam ranah pengajian dan pendidikan diserahkan kepada bidang dakwah dan pendidikan, urusan renovasi diserahkan kepada bidang pengawasan dan pengurus bangunan.

Keempat pola pengawasan itu tetap menjadi tugas bersama pula, pengurus masjid bersama jamaah, dan aparat setempatpun seperti RT/RW menjadi pengawas dalam berlangsungnya kegiatan dakwah disini. Hal ini pula menjadi kekuatan dakwah di masjid Al Munawwaroh. Adanya legitimasi dan dukungan penuh dari para pejabat setempat yang memang hanya masjid satu-satunya yang berbeda di masjid-mesjid sekitarnya. Dilingkungan masjid AL MUnawwaroh rata-rata memiliki banyak masjid dalam satu lingkungan, sehingga unsur-unsur pendukung yang ada menjadi terpecah dan terpisah.

\section{Daftar Pustaka}

[1] Ali, Z. M. (2008). Dasar-Dasar Manajemen. Riau: Suska Press.

[2] Ayub, M. E. (1996). Manajemen Masjid. Jakarta: Gema Insani Press.

[3] Dewi, S. (2015). Metode Penelitian Dakwah. Bandung: PT Remaja Rosdakarya.

[4] Manullang, M. (1983). Dasar-Dasar Manajemen. Jakarta: Galih Indonesia

[5] Ma'arif, B. S. (2010). Komunikasi Dakwah: Paradigma Untuk Aksi. Bandung: PT Remaja Rosdakarya.

[6] Sadiah, D. (2015). Metode Penelitian Dakwah. Bandung: PT Remaja Rosdakarya.

[7] Munir, M. (2007). Manajemen Dakwah. Jakarta: Prenada Media. 